\title{
An evidence for the composition of the Ordovician upper mantle beneath West Sangilen (Southeast Tuva, Russia)
}

\author{
Anastasiya Gibsher ${ }^{1}$, Vladimir Malkovets ${ }^{1}$, Yury Litasov', \\ William Griffin', Suzanne O'Reilly ${ }^{2}$ \\ ${ }^{1}$ Institute of Geology and Mineralogy SB RAS, Novosibirsk, Russia(n.gibsher@gmail.com), \\ ${ }^{2}$ GEMOC National Key Centre, Macquarie University, Sydney, Australia
}

\section{Introduction}

Ultramafic xenoliths in alkaline basaltic rocks are major source of information on the structure and composition of the lithospheric mantle beneath the continents. Although many studies have been carried out on xenoliths from Tertiary and Quaternary magmatic host, far fewer studies have been undertaken on xenolith suites from older magmatic events of orogenic belts. In this paper, we present a study of ultramafic xenoliths from Ordovician lamprophyre dikes of the West Sangilen Highland (Southeast Tuva, Russia).

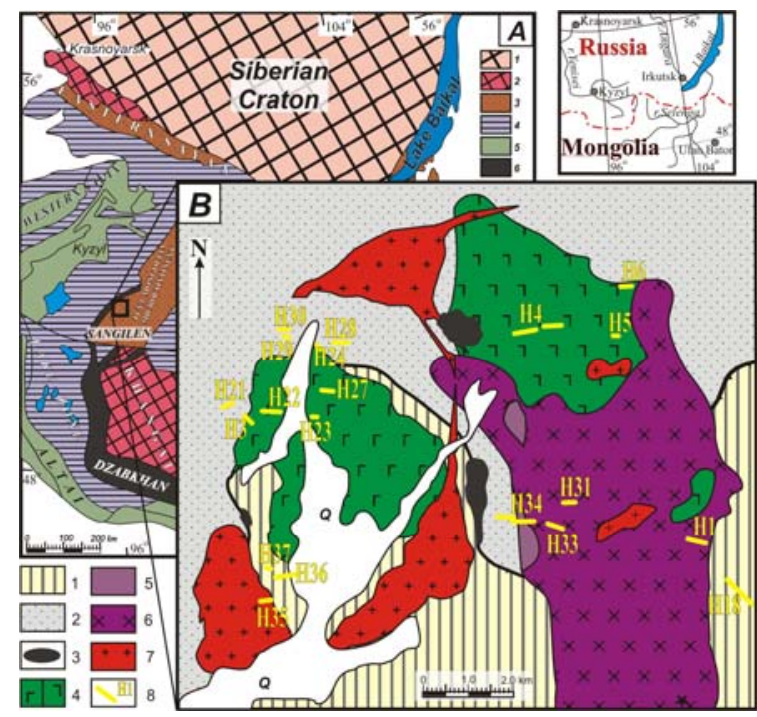

Fig. 1. A - Simplified tectonic scheme of the central part of the Central Asian Orogenic Belt (modified after Vladimirov et al., 1999). 1Siberian craton; 2 - Precambrian microcontinental megablock; 3-Riphean microcontinental blocks; 4-Neoproterozoic mobile belts; 5 - Paleozoic mobile belts; 6 - ophiolites. B - (modified after Egorova et al., 2006) Location map of the lamprophyre dikes. 1 - Precambrian metamorphic rocks, 2 - Cambrian volcanogenic - sedimentary rocks; 3 - serpentinites; 4 - gabbroids; 5 porphyritic monzodiorites; 6 - nonporphyritic monzodiorites; 7 - Ordovician granites; 8 lamprophyre dikes.

\section{Geological setting}

The West Sangilen is a fragment of highly metomorphized structure of Cambrian-Ordovician orogen, which has been formed as a result of Tannuola island arc, Agardag back-arc basin and Sangilen microcontinent pilling-up (Gibsher et al., 2000). Recently, a number of mantle-derived xenoliths have been found in the lamprophyre dikes. The dikes correspond to the last stage of magmatic activity within the region, which belongs to the Late Ordovician orogeny. Ar-Ar dating of amphibole and biotite megacrysts from the lamprophyres provides an age of $441.3 \pm 1.1 \mathrm{Ma}$ (Izokh et al., 2001).

\section{Sample description}

Lamprophyres contain numerous xeno-, mega-, and phenocrystals, as well as abundant xenoliths of lherzolites, harzburgites, clinopyroxenites, and gabbro. The megacryst assemblage includes kaersutite, Al-Ti-augite, anorthoclase, biotite, apatite, and Ti-magnetite.

Peridotite nodules reach up to $50 \mathrm{~cm}$ in diameter and are significantly dominant among the mantlederived xenoliths. They are very fresh, wellpreserved rocks. According to the Frey-Prinz classification (1978), the group I xenoliths are presented by spinel lherzolites, of which the some contain the grains of phlogopite and amphibole, and spinel harzburgites; the group II xenoliths are spinel clinopyroxenites with amphibole and plagioclasespinel-garnet clinopyroxenites. The textures of group I are protogranular (Mercie \& Nicolas, 1975). The textures of group II are cumulative.

\section{Whole rock chemical composition}

The bulk rock analyses of most peridotites reveal negative correlation between $\mathrm{MgO}$ content and $\mathrm{TiO}_{2}, \mathrm{Al}_{2} \mathrm{O}_{3}$, and $\mathrm{CaO}$. It is consistent with traditional concept of partial melting degree of 
primitive mantle lherzolite. Correspondingly, the harzburgites contain less amount of $\mathrm{TiO}_{2}, \mathrm{Al}_{2} \mathrm{O}_{3}$, $\mathrm{CaO}$, and higher $\mathrm{MgO}$ content.
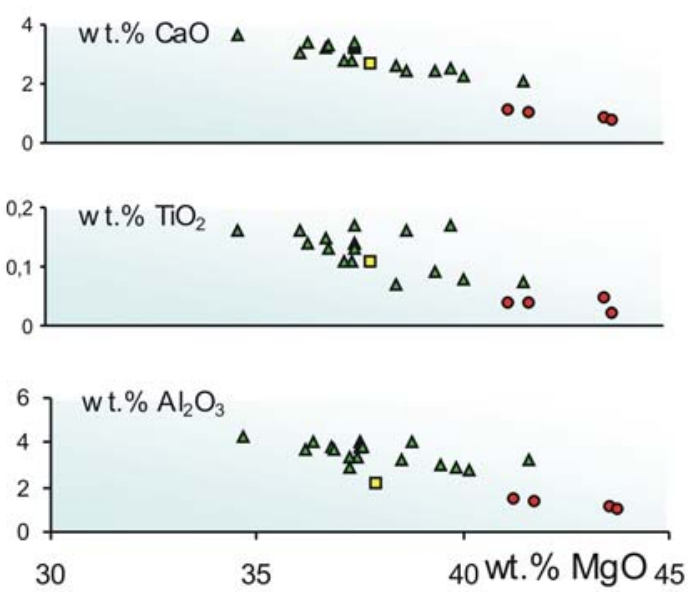

Fig. 2. A plot of MgO versus some major oxides content in bulk rock peridotites. Symbols: triangles - lherzolites; square - phlogopiteamphibole-bearing lherzolite; circles harzburgites.
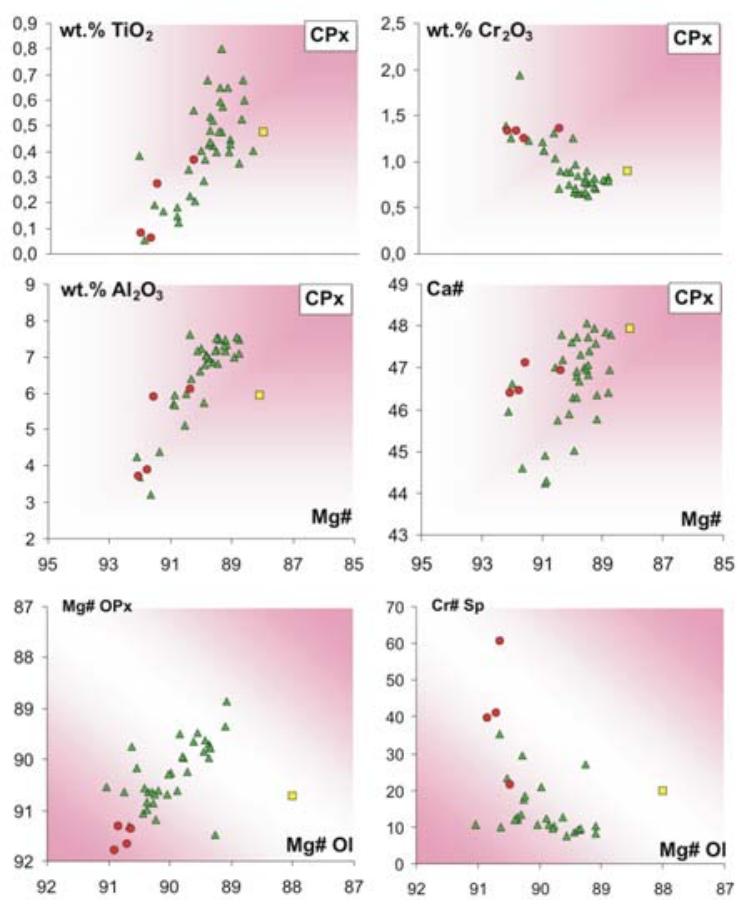

Fig. 3. Compositional variation of major elements in peridotitic minerals. $\mathrm{Mg} \#=100 \mathrm{Mg} /(\mathrm{Mg}+\mathrm{Fe})$, $\mathrm{Ca} \#=100 \mathrm{Ca} /(\mathrm{Ca}+\mathrm{Mg}), \mathrm{Cr} \#=100 \mathrm{Cr} /(\mathrm{Cr}+\mathrm{Al})$; CPx - clinopyroxene, OPx - orthopyroxene, Sp spinel, Ol - olivine. Symbols: triangles lherzolites; square - phlogopite-amphibole-bearing lherzolite; circles - harzburgites.

\section{Mineral chemistry}

Composition of minerals gradually changes from fertile lherzolites to harzburgites. Peridotitic olivine composition fits the mantle array. It has Mg\# values
89-91 \%. NiO contents plot within 0.3-0.4 wt \%. Orthopyroxene from peridotites has $\mathrm{Mg \#}=87$ $91 \%, \mathrm{Al}_{2} \mathrm{O}_{3}=2.3-5.5$ wt $\%, \mathrm{Cr}_{2} \mathrm{O}_{3}=0.28-0.86$ wt \%. Clinopyroxene from peridotites has $\mathrm{Mg \#}=$ 86.8-92.3 \%, $\mathrm{TiO}_{2}=0.01-0.95$ wt \%, $\mathrm{Al}_{2} \mathrm{O}_{3}=3.5-$ 7.5 wt $\%, \mathrm{Cr}_{2} \mathrm{O}_{3}=0.63-1.94$ wt \%. Clinopyroxene from clinopyroxenites has $\mathrm{Mg \#}=79-89 \%$. Clinopyroxene composition differs for spinel clinopyroxenites and plagioclase-spinel-garnet clinopyroxenites (correspondingly, 8.4-9.4 and 8.011.2 wt. \% of $\mathrm{Al}_{2} \mathrm{O}_{3}, 0.87-1.75$ and $0.02-0.26$ wt. \% of $\mathrm{TiO}_{2}$, and 0-0.03 and 0.05-0.25 wt. \% of $\mathrm{Cr}_{2} \mathrm{O}_{3}$ ). Spinel from peridotites has $\mathrm{Mg \#}=60.6-80.3 \%$ and bears $\mathrm{Cr}_{2} \mathrm{O}_{3}=7.2-47.2$ wt. \%, $\mathrm{Al}_{2} \mathrm{O}_{3}=20.4-59.9$ wt \%. Spinel from clinopyroxenites has $\mathrm{Mg \#}=$ 70.2-80.1\%, $\mathrm{Cr}_{2} \mathrm{O}_{3}=0-2.2$ wt. \%, $\mathrm{Al}_{2} \mathrm{O}_{3}=64.4-$ 69.7 wt \%. Garnet from plagioclase-spinel-garnet clinopyroxenites $\left(\mathrm{Pyr}_{65-73}, \mathrm{Alm}_{15-23}\right.$, Gross $\left.12-15\right)$ has $\mathrm{Mg \#}=73.9-82.7 \%, \mathrm{Cr}_{2} \mathrm{O}_{3}=0.08-0.19$ wt. \%, $\mathrm{TiO}_{2}=0.01-0.1$ wt \%. Phlogopites of lherzolite have $\mathrm{Mg \#}=73.8-88.7 \%, \mathrm{Na}_{2} \mathrm{O}=0.4-0.9 \mathrm{wt} \%$, $\mathrm{K}_{2} \mathrm{O}=8.7-9.5$ wt \%, $\mathrm{Al}_{2} \mathrm{O}_{3}=15.4-17.0$ wt \%, $\mathrm{TiO}_{2}$ = 3.7-5.9 wt \%. Amphibole belongs to pargasite with $\mathrm{Mg \#}=87.3-87.6 \%, \mathrm{TiO}_{2}=2.6-4.6$ wt \%, $\mathrm{Al}_{2} \mathrm{O}_{3}=15.3-14.6$ wt \%, $\mathrm{Na}_{2} \mathrm{O}=2.8-3.1$ wt $\%$. Plagioclase from plagioclase-spinel-garnet clinopyroxenites corresponds to labradorite $\left(\mathrm{An}_{52-}\right.$ 66).

\section{Geothermometry}

According to mineral geothermometry, calculated temperatures for spinel lherzolites range from 970 to $1100{ }^{\circ} \mathrm{C}(\mathrm{Ca}-\mathrm{OPx}$, Brey, Kohler, 1990) and from 1040 to $1160^{\circ} \mathrm{C}$ (2-Px, Brey, Kohler, 1990), for spinel clinopyroxenites - from 1024 to $1032{ }^{0} \mathrm{C}$ (Mercier, 1980), for plagioclase-spinel-garnet clinopyroxenites - from 1110 to $1243{ }^{0} \mathrm{C}$ (Ellis, Green, 1979).

\section{Trace elements characteristics of clinopyroxene}

Trace element composition for clinopyroxenes in West Sangilen Highland xenoliths is comparable with those for typical primitive mantle peridotites, which have primitive trace element patterns or minor depletion in LREE, Th, U, and Nb. All clinopyroxenes of fertile spinel peridotites have small negative $\mathrm{Zr}$-Hf-Ti anomalies in chondritenormalized plots. The $\mathrm{La} / \mathrm{Yb}$ ratios in the clinopyroxenes vary from 0.06 to 0.98 .

Clinopyroxenes from several peridotites are slightly enriched in LREE, Sr and depleted in HREE and HFSE. They have $\mathrm{La} / \mathrm{Yb}$ ratios in the clinopyroxenes from 0.72 to 40.02 . 


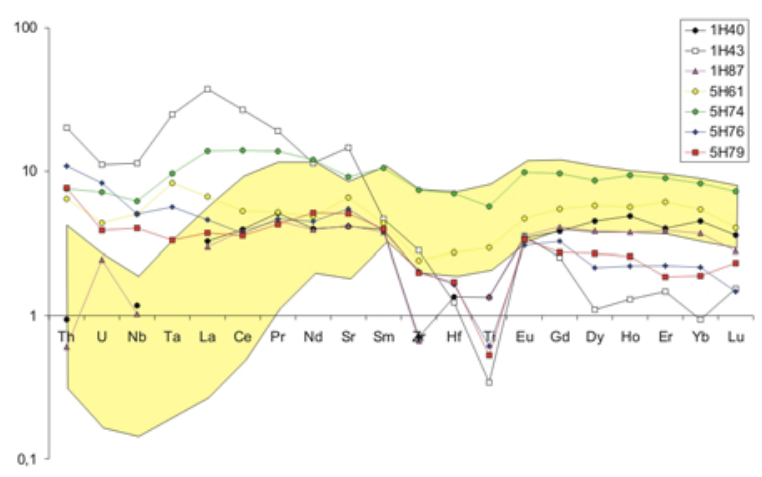

Fig. 4. Chondrite-normalised trace element patterns for clinopyroxene from fertile spinel peridotites. Individual trace elements patterns are shown for spinel peridotites with features of cryptic metasomatism.

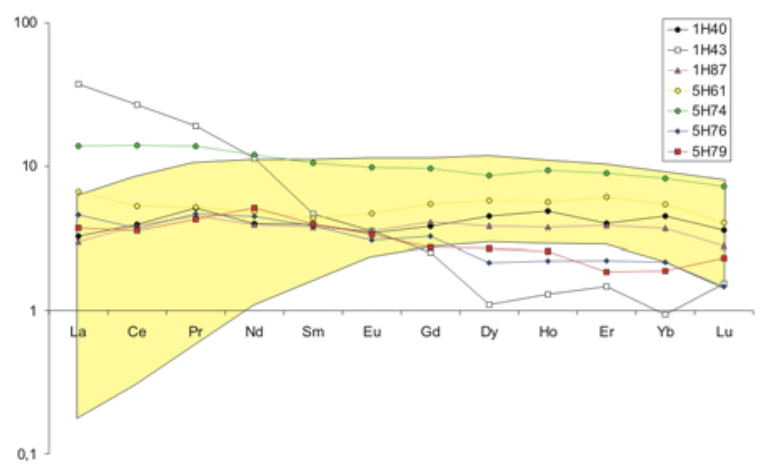

Fig. 5. Chondrite-normalised REE patterns for clinopyroxene from fertile spinel peridotites. Individual trace elements patterns are shown for spinel peridotites with features of cryptic metasomatism.

\section{Results}

The Ordovician lamprophyre dikes of the West Sangilen Highland are of special interest, because they sampled and carried up some pieces of most the ancient mantle under orogenic belts.

The chemical and mineralogical data obtained for the lherzolite nodules from Western Sangilen lamprophyre dikes allow us to suggest following:

(1) The upper mantle domain beneath the Western Sangilen at a depth of the spinel facies consisted of mainly 'dry' lherzolite varieties in the Late Ordovician.

(2) At that time, the local upper mantle column was heterogeneous ranging from fertile to depleted compositions.

(3) Locally, mantle metasomatism occurred under volatile influence (preferably $\mathrm{CO}_{2}$ ).

(4) High geothermal gradient beneath the Western Sangilen during the capture of xenoliths is assumed from relatively high calculated temperatures for the depth of spinel facies.
One of important thing is, that a majority of the Ordovician mantle peridotites, in terms of major element compositions, resembles those from numerous xenolith localities of all over the Quaternary basalts of neighboring Baikal Rift System.

\section{References}

Brey G.P., Köhler T., 1990. Geothermobarometry in four-phase lherzolites II. New thermobarometers, and practical assessment of existing thermobarometers, Journal of Petrology, 31, 13531378.

Egorova V.V., Volkova N.I., Shelepaev R.A, Izokh A.E., 2006. The lithosphere beneath Sangilen Plateau, Siberia: evidence from peridotite, pyroxenite and gabbro xenoliths from alkaline basalts. Mineralogy and Petrology, Mineralogy and Petrology, 88, 419441.

Ellis D.J., Green D.H., 1979. An experimental study of the effect of Ca upon garnet-clinopyroxene $\mathrm{Fe}-\mathrm{Mg}$ exchange equlibria, Contribution to Mineralogy and Petrology, 71, 13-22.

Frey F.A., Prinz M., 1978. Ultramafic inclusions from San Carlos, Arizona: petrologic and geochemical data bearing on their petrogenesis, Earth and Planetary Sciense Letters, 38, 129-176.

Gibsher A.S.; Vladimirov A.G. \& Vladimirov V.G., 2000. The geodynamic nature of Early Pa-leozoic nappe-folded structure of Sangilen upland (SouthEastern Tuva), Dokl Akad Nauk, 370, 489-492.

Izokh A.E., Polyakov G.V., Mal'kovets V.G., Shelepaev R.A., Travin A.V., Litasov Yu. D., Gibsher A. A., 2001. The Late Ordovician Age of Camptonites from the Agardag Complex of Southeastern Tuva as an Indicator of the Plume-Related Magmatism during Collision Processes, Doklady Earth Sciences, 379 (5), 511-514.

McDonough W.F., Sun S.-S., 1995. The composition of the Earth, Chemical Geology, 120, 223-253.

Mercier J.-C.C., 1980. Single-pyroxene geothermometry, Tectonophysics, 70, 1-37.

Mercier J-C.C., Nicolas A., 1975. Textures and fabrics of upper-mantle peridotites as illustrated by xenoliths from basalts. Journal of Petrology, 16 (2), 454-487. 